\title{
In vitro maturation alters gene expression in bovine oocytes
}

\author{
Paulo R. Adona ${ }^{1,2,4}$, Cláudia L.V. Leal ${ }^{4}$,Fernando H. Biase ${ }^{5}$, Tiago H. De Bem ${ }^{4}$, Lígia G. Mesquita ${ }^{4}$, \\ Flávio V. Meirelles ${ }^{4}$,André L. Ferraz ${ }^{6}$, Luiz R. Furlan ${ }^{7}$, Paulo S. Monzani ${ }^{2,3}$ and Samuel Guemra ${ }^{2,3}$ \\ Universidade Norte do Paraná, Arapongas, Brazil; Agropecuária Laffranchi, Tamarana, Brazil; Universidade de São Paulo, \\ Pirassununga, Brazil; Auburn University, USA; Universidade estadual de Mato Grosso do Sul, Aquidauana, Brazil; and \\ Universidade Estadual Paulista, Botucatu, Brazil
}

Date submitted: 12.02.2015. Date revised: 20.10.2015. Date accepted: 29.10.2015

\section{Summary}

Gene expression profiling of in vivo- and in vitro-matured bovine oocytes can identify transcripts related to the developmental potential of oocytes. Nonetheless, the effects of in vitro culturing oocytes are yet to be fully understood. We tested the effects of in vitro maturation on the transcript profile of oocytes collected from Bos taurus indicus cows. We quantified the expression of 1488 genes in in vivo- and in vitromatured oocytes. Of these, 51 genes were up-regulated, whereas 56 were down-regulated ( $\geq 2$-fold) in in vivo-matured oocytes in comparison with in vitro-matured oocytes. Quantitative real-time polymerase chain reaction (PCR) of nine genes confirmed the microarray results of differential expression between in vivo- and in vitro-matured oocytes (EZR, EPN1, PSEN2, FST, IGFBP3, RBBP4, STAT3, FDPS and IRS1). We interrogated the results for enrichment of Gene Ontology categories and overlap with protein-protein interactions. The results revealed that the genes altered by in vitro maturation are mostly related to the regulation of oocyte metabolism. Additionally, analysis of protein-protein interactions uncovered two regulatory networks affected by the in vitro culture system. We propose that the differentially expressed genes are candidates for biomarkers of oocyte competence. In vitro oocyte maturation can affect the abundance of specific transcripts and are likely to deplete the developmental competence.

\section{Introduction}

Cumulus-oocyte complexes (COCs) are dependent on adequate gene expression to initiate and to undergo oocyte maturation (meiotic progression) and embryonic development (Labrecque et al., 2013; Li et al., 2013). The mechanisms by which oocytes acquire competence to develop up to the blastocyst stage

\footnotetext{
${ }^{1}$ All correspondence to: Paulo R. Adona. Agropecuária Laffranchi. PO box 45. Zip Code: 86125-000 Tamarana, Paraná. Brazil. Tel: +55 43 33994700. E-mail: paulo_adona@yahoo.com.br

${ }^{2}$ Escola de Medicina Veterinária, Universidade Norte do Paraná, Arapongas, PR, Brazil.

${ }^{3}$ Laboratório de Reprodução Animal, Agropecuária Laffranchi, Tamarana, PR, Brazil.

${ }^{4}$ Departamento de Ciências Básicas, Universidade de São Paulo, Pirassununga, SP, Brazil.

${ }^{5}$ Department of Animal Sciences, Auburn University, Auburn, AL, USA.

${ }^{6}$ Escola de Zootecnia, Universidade estadual de Mato Grosso do Sul, Aquidauana, MS, Brazil.

${ }^{7}$ Departamento de Tecnologia, Universidade Estadual Paulista, Botucatu, SP, Brazil.
}

are still not fully understood. There is evidence that the acquisition of competence is correlated with RNA and protein molecules processed and stored during growth and maturation periods (Ferreira et al., 2009; Caixeta et al., 2013). To enable the storage and the convenient use of the molecules stored in oocytes, several mechanisms should act efficiently (Gandolfi \& Gandolfi, 2001; Tomek et al., 2002). Some transcripts have already been associated with oocyte developmental competence (Caixeta et al., 2009; KatzJaffe et al., 2009; Biase et al., 2010; Kanka et al., 2012; Bessa et al., 2013; Biase et al., 2014), and those results support the hypothesis that specific RNAs or proteins produced during oogenesis contribute to oocyte competence (Sirard et al., 2006).

It is estimated that during embryogenesis about 5000-10,000 genes are simultaneously expressed in oocytes with a high level of control (Niemann et al., 2007). The transcripts for key transcription factors represent a small number of copies and the ones that encode most of the structural proteins may represent approximately $2 \%$ of the mRNA pool (Yu et al., 2002). Approximately $10-20 \%$ of total RNA consists of 
polyadenylated mRNAs (Niemann et al., 2007), which are associated with oocyte developmental competence (Pocar et al., 2001; Biase et al., 2008; Biase et al., 2010).

The molecular mechanisms that govern oocyte competence are mostly still unknown. However, some oocyte-specific genes have been described revealing their importance in promoting embryogenesis (KatzJaffe et al., 2009; Biase et al., 2010; Belli et al., 2013; Bessa et al., 2013; Biase et al., 2014). The profiling of gene expression in oocytes during maturation may help us understand the regulation of oocyte competence to mature and to sustain embryo development during the first two cleavages (Fair et al., 2007). It also promotes the identification of molecular markers for oocyte developmental potential. Nonetheless, most studies have addressed this subject in taurine subspecies (Bos taurus taurus). Here, we performed microarray-based transcriptome analyses of in vivo- and in vitro-matured bovine oocytes collected from Bos taurus indicus cows in order to enrich our knowledge of genes involved in the acquisition of oocyte competence.

\section{Materials and methods}

\section{Estrous synchronization and superovulation protocols}

Eight Nelore cows (crossbred) with good body condition and in reproductive age were synchronized on random days of the estrous cycle (D0) by intramuscular (IM) application of $2 \mathrm{mg}$ estradiol benzoate RIC-BE (Tecnopec) and with placement of a bovine intravaginal progesterone device (Schering) for 8 days. On the fourth day (D4) follicle-stimulating hormone (FSH) treatment (Follitropin-V, Vetrepharm) was initiated with decreasing doses $(80,60,40$ or $20 \mathrm{mg}$ FSH - IM) during 4 consecutive days. Simultaneously with the last FSH application (D7), cows received 0.150 mg Prolise (D-cloprostenol, IM), a PGF $_{2 \alpha}$ analogue (Tecnopec), and after $36 \mathrm{~h}$ (D8), the animals were separated randomly into two groups of four animals for oocyte collection.

One group $(n=4)$ was designated for collection of immature oocytes at the germinal vesicle stage (GV). The intravaginal progesterone device was removed from the cows at D8 and oocyte collection was performed by ultrasound-guided follicular aspiration ovum pick up (OPU) so that they could be matured in vitro.

The second group $(n=4)$ was designated for collection of in vivo-matured (MII) oocytes. The intravaginal progesterone device was removed from the cows at D8, $25 \mathrm{mg}$ luteinizing hormone (LH) (Lutropin-V, Vetrepharm, IM) was administered and we performed OPU 22-24 h later for collection of MII oocytes. OPU was performed three times in the same animals at intervals of approximately 80 days between the synchronizations.

\section{Oocytes selection criteria}

During the three collections for each group, we selected only those follicles with diameter greater than $8 \mathrm{~mm}$ for OPU. Cumulus-oocyte complexes collected at GV stage were used for in vitro maturation if the oocyte presented homogeneous cytoplasm and at least two compact layers of cumulus cells. Cumulus-oocyte complexes collected at MII phase were used for further procedures if the oocyte presented homogeneous cytoplasm and several layers of expanded cumulus cells.

The procedures involving animal handling were approved by the Ethics Committee of the University of São Paulo - School of Animal Sciences and Food Engineering.

\section{In vitro maturation of $\mathrm{GV}$ oocytes}

Oocytes collected at GV phase were matured in vitro for $22 \mathrm{~h}$ in TCM-199 medium (Sigma) supplemented with $10 \%$ bovine fetal serum (Sigma), $5.0 \mu \mathrm{g} / \mathrm{ml}$ $\mathrm{LH}, 0.5 \mu \mathrm{g} / \mathrm{ml} \mathrm{FSH}, 200 \mu \mathrm{M}$ pyruvate (Sigma), and $50 \mu \mathrm{g} / \mathrm{ml}$ gentamicin (Sigma). In vitro maturation culture was carried out in $100 \mu$ droplets (20-25 oocytes in each droplet) under mineral oil at $38.5^{\circ} \mathrm{C}$ and an atmosphere of $5 \% \mathrm{CO}_{2}$ in air.

\section{RNA extraction and amplification}

For each of the three replicates, we selected 50 in vitromatured and 50 in vivo-matured oocytes presenting the first polar body after removal of cumulus cells. The oocytes were pooled and stored at $-80^{\circ} \mathrm{C}$ in calciumand magnesium-free phosphate-buffered saline (PBS) with $0.1 \%$ polyvinyl alcohol (PVA) and $100 \mathrm{U} / \mathrm{ml}$ RNase inhibitor (Invitrogen). RNA extraction from oocytes was performed using RNeasy Protect Mini Kit (Qiagen) following the manufacturer's recommendations. Total RNA ( 10 ng) was used as template for mRNA amplification with the SuperScript RNA Amplification Kit (Invitrogen) following the manufacturer's recommendations and oligo(dT) $)_{12-18}$ as primers. Samples of amplified mRNA (mRNAa) were assayed in a Bioanalyzer 2100 equipment to assess quality and integrity using the RNA 6000 LabChip kit, following the manufacturer's recommendations (Agilent Technologies).

\section{Probe labelling and microarray hybridization}

Hybridization probes from the mRNAa were prepared by reverse transcription followed by the incorporation of $\mathrm{Cy} 3$ or $\mathrm{Cy} 5$ fluorophores according to the 
recommendations of CyScribe Post-Labelling Kit and CyScribe GFX Purification (GE Healthcare). cDNA labelled with $\mathrm{Cy} 3$ or $\mathrm{Cy} 5$ was measured in a NanoDrop 2000 spectrophotometer. Hybridizations were performed on microarray slides (BLO Plus (GPL9176)), containing oligonucleotides (70-mer) representing 8400 bovine genes. This long oligo set includes 10 bovine control genes and 10 Stratagene Alien Genes spotted multiple times on the array. Approximately $400 \mathrm{ng}$ of labelled cDNA was hybridized to the microarray, following the dye-swap schema with two technical replicates. Thus, for each of the three biological replicates, we hybridized four slides, composing 12 slides for the experiment. Hybridization was carried in an automated station (Tecan HS400) for $6 \mathrm{~h}$ at $42^{\circ} \mathrm{C}$, for $6 \mathrm{~h}$ at $35^{\circ} \mathrm{C}$ and for $6 \mathrm{~h}$ at $30^{\circ} \mathrm{C}$, followed by three washes in $2 \times$ sodium chloride and sodium citrate (SSC), $1 \%$ sodium dodecyl sulfate (SDS) at $37^{\circ} \mathrm{C}$, three washes in $0.1 \times \mathrm{SSC}, 0.1 \% \mathrm{SDS}$ at $30^{\circ} \mathrm{C}$ and other three washes in $0.1 \times \mathrm{SSC}$ at $25^{\circ} \mathrm{C}$.

\section{Data collection and analysis}

The array images were digitalized by GenePix 4000B (Axon Instruments). The images were compiled using Imagene 5.0 (BioDiscovery), followed by the identification of the points of fluorescence and by background reading.

Raw intensities were normalized by the Lowess local regression using the LIMMA computational package according to procedures recommended for dye-swap labelling (Smyth \& Speed 2003; Smyth 2005). The data obtained from the array spots were filtered and processed in order to eliminate poor quality, saturated or low fluorescence intensity spots relative to the background. Following data normalization, spots with intensity two-fold or greater than the background were considered for downstream analysis. Student's $t$-test was used to assess the statistical significance between the gene expression data generated from two experimental groups. Genes were inferred as differentially expressed between in vivo- and in vitromatured oocytes if fold change was $\geq 2$ and $P$-value $<0.05$.

The list of differentially expressed genes (DEG) was queried for biological processes potentially affected by in vitro maturation of oocytes using DAVID Bioinformatics Resources (v6.7, (Huang et al., 2009)). The probabilities of significance were adjusted for multiple hypotheses testing using false discovery rate (FDR) (Benjamini \& Yekutieli 2001), and a Gene Ontology term was assumed enriched if FDR $<0.1$. The DEGs were overplayed on the topology of a protein-protein network according to the human and mouse BioGRID (v.3.2) database (ChatrAryamontri et al., 2013) The network was built by expanding one protein interaction from each gene. The putative protein-protein network with DEGs in oocytes was visualized in Cytoscape (Shannon et al., 2003).

\section{Validation of the microarray results}

In order to validate the microarray, cDNA was synthesized from the mRNAa used for the preparation of probes. The nine genes with the greatest difference in expression between in vivoand in vitro-matured oocytes and known to be associated with the physiology of oocyte maturation were chosen for validation. Five of those genes were up-regulated (EZR, EPN1, PSEN2, FST, and $I G F B P 3)$, and four genes were down-regulated (RBBP4, STAT3, FDPS, IRS1) in in vivo-matured oocytes. Primers and probes for TaqMan Gene Expression Assays were designed by the manufacturer (EZR (Bt03223252_m1), EPN1 (Bt03233436_g1), PSEN2 (Bt03237484_m1), FST (Bt03259671_m1) and IGFBP3 (Bt03223808_m1), RBBP4 (Bt03230465_g1), STAT3 (Bt03259866_g1), FDPS (Bt03216346_g1), Applied Biosystems). The exception was IRS1 whose primers (GGCAGATCTGGATAATCGGT, AATGGAAGCCACAGAGGACT) and probe (CGGACTCACTCTGCGGGCAC) were made to order.

Reverse transcription was performed with the SuperScript II kit, following the manufacturer's recommendations (Invitrogen) and oligo $(\mathrm{dT})_{12-18}$ as primers. The real-time PCR reactions were set up according to the TaqMan PCR Master Mix Kit (Applied Biosystems). Real-time PCR data were normalized relative to $\mathrm{H} 2 \mathrm{~A}$ histone family gene, member $\mathrm{Z}$ (H2AFZ, Bower et al., 2007) and fold changes were calculated according to the $2^{-\Delta \Delta C T}$ method (Livak \& Schmittgen, 2001). We used the in vivo-matured oocytes as calibrator sample. The $\Delta C T$ s were used as input for analysis of variance (BioEstats 5.0) (Ayres et al., 2007) to assess the significance of differential gene expression between the two groups (Yuan et al., 2006). Differential gene expression between in vivoor in vitro-matured oocytes was assumed significant when $P<0.05$.

\section{Results}

\section{Genes expressed in bovine oocytes matured in vivo and in vitro}

Our experiment yielded 1488 genes quantified with two-fold or greater intensity than the background. Among these, 51 genes were up-regulated ( $\geq 2$-fold) in in vivo-matured oocytes compared with in vitro counterparts (Table 1). By comparison, 56 genes were 
Table 1 Genes up-regulated in in vivo-matured oocytes compared with in vitro counterparts

\begin{tabular}{|c|c|c|c|}
\hline Symbol & Gene & Accession no. & Ratio (in vivo/in vitro) \\
\hline$E Z R$ & ezrin & NM_174217.2 & 5.74 \\
\hline$L A P 3$ & leucine aminopeptidase 3 & NM_174098.3 & 4.59 \\
\hline EPN1 & epsin 1 & NM_001038670.1 & 4.51 \\
\hline$C F B$ & complement factor B & NM_001040526.1 & 4.12 \\
\hline GAP43 & growth associated protein 43 & NM_203358.2 & 3.99 \\
\hline ATHL1 & acid trehalase-like & XM_589347.6 & 3.95 \\
\hline SMARCC1 & SWI/SNF, actin & XM_002707780.2 & 3.88 \\
\hline COL13A1 & collagen, type XIII, alpha 1 & NM_001105433.1 & 3.84 \\
\hline MED29 & mediator complex subunit 29 & NM_001080316.2 & 3.77 \\
\hline$M M A B$ & methylmalonic aciduria cblB type & NM_001079632.1 & 3.70 \\
\hline$L C K$ & lymphocyte-specific protein tyrosine $\mathrm{k}$ & NM_001034334.1 & 3.66 \\
\hline$A P 2 A 2$ & adaptor-related protein $2, \alpha 2$ & NM_001075702.1 & 3.57 \\
\hline SPHK2 & sphingosine kinase 2 & XM_002695198.2 & 3.51 \\
\hline$R P L P 2$ & ribosomal protein, large, $\mathrm{P} 2$ & NM_174788.4 & 3.46 \\
\hline EPHB3 & $\mathrm{EPH}$ receptor $\mathrm{B} 3$ & NM_001192796.1 & 3.33 \\
\hline PLK1 & polo-like kinase 1 & NM_001038173.2 & 3.32 \\
\hline MRPS10 & mitochondrial ribosomal prot. S10 & NM_001035314.2 & 3.30 \\
\hline PSEN2 & presenilin 2 & NM_174440.4 & 3.28 \\
\hline$D G K A$ & diacylglycerol kinase, alpha $80 \mathrm{kDa}$ & NM_001077860.1 & 3.27 \\
\hline FST & follistatin & NM_175801.3 & 3.25 \\
\hline PIK3R6 & phosphoinositide-3-kinase, R6 & NM_001102028.2 & 3.21 \\
\hline$N A D K$ & NAD kinase & NM_001034445.1 & 3.15 \\
\hline COX6A2 & cytochrome c oxidase sub. $6 \mathrm{~A} 2$ & NM_174522.2 & 2.90 \\
\hline RPS6KB2 & ribosomal protein $\mathrm{S} 6 \mathrm{~K}, 70 \mathrm{kDa}, 2$ & NM_001205582.1 & 2.78 \\
\hline DYNLL1 & dynein, light chain, LC8-type 1 & NM_001003901.1 & 2.73 \\
\hline ETFB & electron-transfer-flavoprotein, $\beta$ & NM_001038582.1 & 2.67 \\
\hline NUMA1 & nuclear mitotic apparatus protein 1 & NM_001205746.1 & 2.66 \\
\hline ADIPOQ & adiponectin, C1Q collagen & NM_174742.2 & 2.63 \\
\hline PTPRCAP & protein tyrosine phosphatase & NM_001046618.1 & 2.50 \\
\hline NGFRAP1 & nerve growth factor receptor & NM_001163777.2 & 2.50 \\
\hline TACC 3 & transforming, acidic coiled-coil & NM_001100305.2 & 2.47 \\
\hline LTBP3 & latent transforming growth factor $b$ & NM_001192738.1 & 2.47 \\
\hline IGFBP5 & IGF-binding protein 5 & NM_001105327.2 & 2.37 \\
\hline STARD13 & StAR-related lipid transfer & NM_001192070.1 & 2.37 \\
\hline POLR2E & polymerase (RNA) II, $25 \mathrm{kDa}$ & NM_001038093.2 & 2.35 \\
\hline$U B E 2 B$ & ubiquitin-conjugating enzyme E2B & NM_001037459.2 & 2.30 \\
\hline FSD1 & fibronectin type III and SPRY domain & NM_001081518.1 & 2.30 \\
\hline CFDP1 & craniofacial development protein 1 & NM_174268.1 & 2.26 \\
\hline PHF19 & PHD finger protein 19 & NM_001192715.1 & 2.25 \\
\hline PLOD3 & procollagen-lysine, 2-oxoglutarate & NM_001193255.1 & 2.21 \\
\hline IGFBP3 & IGF-binding protein 3 & NM_174556.1 & 2.20 \\
\hline G6PC3 & glucose 6 phosphatase, catalytic, 3 & NM_183364.3 & 2.20 \\
\hline KEAP1 & kelch-like ECH-associated protein 1 & NM_001101142.1 & 2.16 \\
\hline ITGA11 & integrin, alpha 11 & XM_002690525.2 & 2.16 \\
\hline MYF6 & myogenic factor 6 (herculin) & NM_181811.1 & 2.15 \\
\hline STK39 & serine threonine kinase 39 & NM_001075826.1 & 2.12 \\
\hline ARFRP1 & ADP-ribosylation factor related & NM_001037607.1 & 2.11 \\
\hline WDR5 & WD repeat domain 5 & NM_001105475.2 & 2.11 \\
\hline SAP30L & SAP30-like & NM_001191372.1 & 2.05 \\
\hline POLRMT & polymerase (RNA) mitochondrial & NM_001205551.1 & 2.04 \\
\hline GHR & growth hormone receptor & NM_176608.1 & 2.02 \\
\hline
\end{tabular}

down-regulated ( $\geq 2$-fold) in in vivo-matured oocytes (Table 2). Among these 107 DEGs genes, 25 genes were annotated to the enriched Gene Ontology (GO) biological process 'negative regulation of cellular process' (FDR $<0.1$, Table 3). Noticeably, several of these 25 DEGs are also possibly associated with regulation of metabolic processes (FDR $<0.2$, Table 3). Further inspection of these 25 DEGs demonstrated 
Table 2 Genes down-regulated in in vivo-matured oocytes compared to in vitro counterparts

\begin{tabular}{|c|c|c|c|}
\hline Symbol & Gene & Accession no. & Ratio (in vivo/in vitro) \\
\hline IRS1 & insulin receptor substrate- 1 & XM_003585773.2 & 0.17 \\
\hline$H 3 F 3 A$ & H3 histone, family 3A & NM_001014389.2 & 0.20 \\
\hline SUCLG2 & succinate-CoA ligase, GDP form & NM_001034639.1 & 0.21 \\
\hline CNOT7 & CCR4-NOT transcription complex & NM_001034312.1 & 0.22 \\
\hline SUPT3H & suppressor of Ty 3 homolog & NM_001105008.1 & 0.22 \\
\hline RDH10 & retinol dehydrogenase 10 & NM_174734.2 & 0.23 \\
\hline CXCR5 & chemokine C-X-C motif) R5 & NM_001011675.1 & 0.24 \\
\hline$R B B P 7$ & retinoblastoma binding protein 7 & NM_001034638.1 & 0.24 \\
\hline GOPC & Golgi associated PDZ and coiled-coil & NM_001206157.1 & 0.24 \\
\hline LGTN & ligatin & ВТ021884.1 & 0.25 \\
\hline$B A Z 1 A$ & bromodomain adjacent to zinc finger & NM_001192940.1 & 0.25 \\
\hline$R B B P 4$ & retinoblastoma binding protein 4 & NM_001077013.2 & 0.25 \\
\hline HMGB2 & high-mobility group box 2 & NM_001037616.1 & 0.26 \\
\hline$H D A C 2$ & histone deacetylase 2 & NM_001075146.1 & 0.26 \\
\hline LRRC1 & leucine rich repeat containing 1 & NM_001205469.1 & 0.26 \\
\hline RBP4 & retinol binding protein 4 & NM_001040475.2 & 0.26 \\
\hline TMSB4X & thymosin beta $4, \mathrm{X}$-linked & NM_001002885.1 & 0.27 \\
\hline GBP5 & guanylate binding protein 5 & NM_001075746.1 & 0.27 \\
\hline TPX2 & TPX2, microtubule-associated, targeting protein for Xklp2 & NM_001098898.1 & 0.27 \\
\hline NDUFA1 & NADH dehydrogenase 1 alpha & NM_175794.2 & 0.27 \\
\hline KIAA1310 & KIAA1310 ortholog & NM_001099172.1 & 0.28 \\
\hline FLNC & filamin $\mathrm{C}$, gamma & NM_001206990.1 & 0.28 \\
\hline STAT3 & transducer and activator of transcription & NM_001012671.2 & 0.28 \\
\hline CALML5 & calmodulin-like & NM_001098049.2 & 0.28 \\
\hline LMAN1 & lectin, mannose-binding, 1 & NM_001098943.2 & 0.28 \\
\hline HSPA9 & heat shock 70 protein 9 (mortalin) & NM_001034524.1 & 0.29 \\
\hline KAT2A & K (lysine) acetyltransferase 2A & NM_021078.2 & 0.29 \\
\hline HPRT1 & hypoxanthine phosphoribosyltransferase & NM_001034035.2 & 0.31 \\
\hline DEF6 & differentially expressed in FDCP 6 & NM_001098994.1 & 0.32 \\
\hline YIF1A & Yip1 interacting factor homolog A & NM_001034269.2 & 0.32 \\
\hline RASA1 & RAS p21 protein activator 1 & NM_174449.2 & 0.32 \\
\hline SFT2D1 & SFT2 domain containing 1 & NM_001034551.1 & 0.35 \\
\hline SLC7A14 & solute carrier family $7, \mathrm{n} 14$ & NM_001077992.2 & 0.35 \\
\hline$M O B K L 2 A$ & MOB1, Binder kinase activator & ВТ02̄1734.1 & 0.36 \\
\hline CCNB1 & cyclin B1 & NM_001045872.1 & 0.36 \\
\hline NR1H2 & nuclear receptor subfamily $1, \mathrm{H} 2$ & NM_001014883.1 & 0.37 \\
\hline PATZ1 & POZ and AT hook containing zinc & NM_001191197.1 & 0.37 \\
\hline SNRPF & small nuclear ribonucleoprotein $\mathrm{F}$ & NM_001195027.1 & 0.37 \\
\hline$D E D D$ & death effector domain containing & NM_001034643.2 & 0.37 \\
\hline KNG1 & kininogen 1 & NM_175774.3 & 0.37 \\
\hline ATF2 & activating transcription factor 2 & NM_001081584.2 & 0.38 \\
\hline SLC34A2 & solute carrier family $34, \mathrm{n} 2$ & NM_174661.2 & 0.38 \\
\hline SOX18 & SRY sex region Y)-box 18 & NM_001075789.1 & 0.40 \\
\hline SNRPE & small nuclear ribonucleoprotein $\mathrm{E}$ & NM_001083459.2 & 0.42 \\
\hline MID1 & midline 1 & NM_001192822.1 & 0.43 \\
\hline NCOA1 & nuclear receptor coactivator 1 & NM_001206215.1 & 0.43 \\
\hline IDUA & iduronidase, alpha-L & XM_002688446.2 & 0.43 \\
\hline CTNNB1 & catenin beta 1 & NM_001076141.1 & 0.44 \\
\hline FLRT3 & fibronectin leucine rich transmembrane & NM_001192674.1 & 0.44 \\
\hline SEPHS1 & selenophosphate synthetase 1 & NM_001075316.1 & 0.45 \\
\hline TSSC1 & Tumor suppressing subtransferable & NM_001191328.1 & 0.45 \\
\hline FDPS & farnesyl diphosphate synthase & NM_177497.2 & 0.46 \\
\hline GGT7 & gamma-glutamyltransferase 7 & NM_001076401.1 & 0.47 \\
\hline$S L C 2 A 8$ & solute carrier family 2 member 8 & NM_201528.1 & 0.47 \\
\hline TMEM59L & transmembrane protein 59-like & NM_001075301.1 & 0.49 \\
\hline NPHP1 & nephronophthisis 1 & NM_001105332.1 & 0.49 \\
\hline
\end{tabular}


Table 3 Top 10 GO biological processes associated with DEG between in vivo- and in vitro-matured oocytes

\begin{tabular}{|c|c|c|c|c|}
\hline Category & Term & $P$-value & FDR & Gene symbols \\
\hline GO:0048513 & Organ development & 0.0003 & 0.0566 & $\begin{array}{l}\text { RBP4, HMGB2, FST, ITGA11, HPRT1, CTNNB1, EZR, CXCR5, PATZ1, SOX18, CALML5, } \\
\text { RASA1, IDUA, GHR, MYF6, SPHK2, COL13A1, TACC3, IRS1, STAT3, CCNB1, } \\
\text { SMARCC1, LCK, PSEN2, GAP43, IGFBP5 }\end{array}$ \\
\hline GO:0048523 & $\begin{array}{l}\text { Negative regulation of cellular } \\
\text { process }\end{array}$ & 0.0003 & 0.0566 & $\begin{array}{l}\text { RBP4, HMGB2, DEDD, FST, CTNNB1, NR1H2, DYNLL1, GOPC, RASA1, HSPA9, MYF6, } \\
\text { KNG1, RBBP4, SPHK2, RBBP7, MID1, IRS1, ADIPOQ, STAT3, HDAC2, PSEN2, } \\
\text { CFDP1, TMSB4X, IGFBP3, IGFBP5 }\end{array}$ \\
\hline GO:0031324 & $\begin{array}{l}\text { Negative regulation of cellular } \\
\text { metabolic process }\end{array}$ & 0.0014 & 0.1280 & $\begin{array}{l}\text { MYF6, HMGB2, DEDD, FST, RBBP7, ADIPOQ, STAT3, CTNNB1, NR1H2, HDAC2, } \\
\text { DYNLL1, PSEN2, IGFBP3, IGFBP5 }\end{array}$ \\
\hline GO:0009892 & $\begin{array}{l}\text { Negative regulation of } \\
\text { metabolic process }\end{array}$ & 0.0029 & 0.1280 & $\begin{array}{l}\text { MYF6, HMGB2, DEDD, FST, RBBP7, ADIPOQ, STAT3, CTNNB1, NR1H2, HDAC2, } \\
\text { DYNLL1, PSEN2, IGFBP3, IGFBP5 }\end{array}$ \\
\hline GO:0031325 & $\begin{array}{l}\text { Positive regulation of cellular } \\
\text { metabolic process }\end{array}$ & 0.0030 & 0.1280 & $\begin{array}{l}\text { MYF6, HMGB2, HPRT1, CNOT7, ADIPOQ, IRS1, STAT3, CTNNB1, NR1H2, CCNB1, } \\
\text { NCOA1, HDAC2, PLK1, SMARCC1, GHR }\end{array}$ \\
\hline GO:0048522 & $\begin{array}{l}\text { Positive regulation of cellular } \\
\text { process }\end{array}$ & 0.0035 & 0.1280 & $\begin{array}{l}\text { MYF6, KNG1, RBP4, HMGB2, SPHK2, DEDD, CNOT7, HPRT1, ADIPOQ, IRS1, STAT3, } \\
\text { CTNNB1, NR1H2, CCNB1, NCOA1, HDAC2, DYNLL1, PLK1, SMARCC1, LCK, PSEN2, } \\
\text { NGFRAP1, IGFBP3, GHR }\end{array}$ \\
\hline GO:0043434 & $\begin{array}{l}\text { Response to peptide hormone } \\
\text { stimulus }\end{array}$ & 0.0044 & 0.1280 & SLC2A8, RBP4, UBE2B, IRS1, STAT3, GHR \\
\hline GO:0045185 & $\begin{array}{l}\text { Maintenance of protein } \\
\text { location }\end{array}$ & 0.0045 & 0.1280 & EZR, GOPC, TMSB4X, TACC3 \\
\hline GO:0009893 & $\begin{array}{l}\text { Positive regulation of } \\
\text { metabolic process }\end{array}$ & 0.0046 & 0.1280 & $\begin{array}{l}\text { MYF6, HMGB2, HPRT1, CNOT7, ADIPOQ, IRS1, STAT3, CTNNB1, NR1H2, CCNB1, } \\
\quad \text { NCOA1, HDAC2, PLK1, SMARCC1, GHR }\end{array}$ \\
\hline GO:0031323 & $\begin{array}{l}\text { Regulation of cellular } \\
\text { metabolic process }\end{array}$ & 0.0047 & 0.1280 & $\begin{array}{l}\text { SUPT3H, HMGB2, DEDD, FST, KEAP1, HPRT1, CNOT7, ATF2, CTNNB1, DGKA, } \\
\text { NR1H2, DYNLL1, MED29, PATZ1, SOX18, SAP30L, RASA1, GHR, KAT2A, MYF6, } \\
\text { RBBP4, SPHK2, RBBP7, IRS1, ADIPOQ, STAT3, CCNB1, NCOA1, PHF19, BAZ1A, } \\
\text { HDAC2, PLK1, SMARCC1, PSEN2, IGFBP3, GAP43, IGFBP5 }\end{array}$ \\
\hline
\end{tabular}




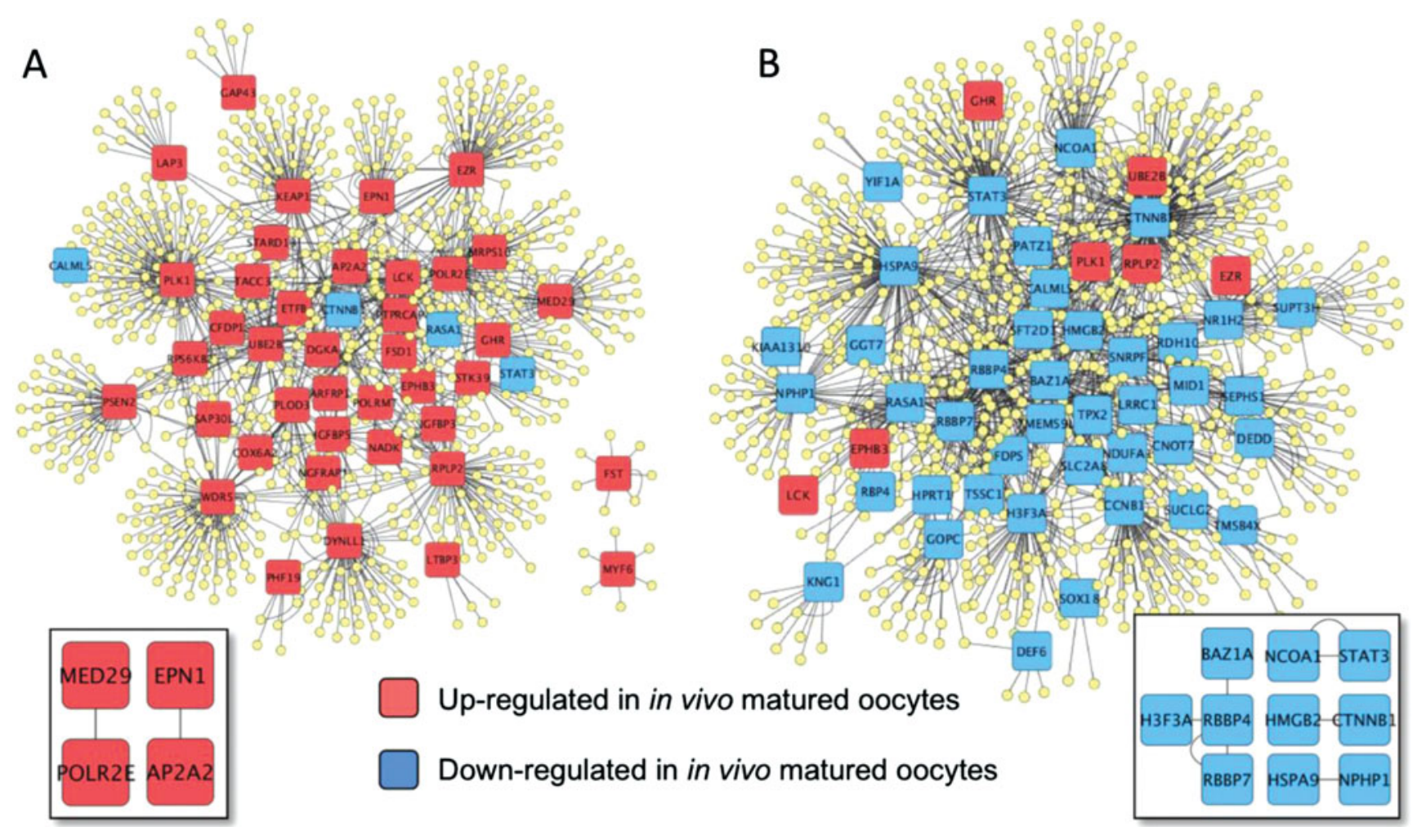

Figure 1 Regulatory protein-protein network of genes affected by the in vitro culture of oocytes. $(A)$ Genes up-regulated in in vivo-matured (MII) oocytes collected in vivo. (B) Genes down-regulated in MII oocytes collected in vivo. Differentially expressed genes (DEGs) are marked in red or blue, and yellow depicts the proteins potentially interacted with DEGs. The insets highlight the direct connection between proteins whose coding genes are differentially regulated by in vitro maturation.

that nine of them are involved in regulation of transcription (CTNNB1, DEDD, FST, HMGB2, HDAC2, MYF6, NR1H2, RBBP7, STAT3).

Next, we searched for altered gene expression that would affect interacting proteins. Most DEGs were part of a protein-protein network. Forty out of 51 genes up-regulated in in vivo-matured oocytes composed a protein interaction network (Fig. 1A), four of those genes identified two pairs of direct protein-protein interaction (Fig. $1 A$, inset). Two of those genes are associated with the transcription complex, namely: polymerase (RNA) II (DNA directed) polypeptide $\mathrm{A}$ and the Mediator Complex Subunit 29. By comparison, 41 of the 56 genes up-regulated in in vitro-matured oocytes composed another protein-protein network (Fig. 1B), 10 of which identified direct protein interactions (Fig. 1B, inset). It is noteworthy that we found four genes associated with chromatin remodelling factors that were positively modulated by in vitro culture, namely: $\mathrm{H} 3$ histone, family3 $\mathrm{A}$, retinoblastoma binding protein 4 and 7 , and bromodomain adjacent to zinc finger domain, $1 \mathrm{~A}$.

\section{Confirmation of differentially expressed genes by real-time PCR}

We used real-time PCR to validate our microarray results. The nine genes tested were differentially expressed in in vivo-matured oocytes (EZR, EPN1, IRS1, FDPS, FST, IGFBP3, PSEN2, RBBP4, STAT3) compared with in vitro-matured oocytes in the two analyses, microarray and RT-PCR $(P<0.05$. Fig. 2$)$.

\section{Discussion}

We determined whether the in vitro maturation process affected the gene expression of oocytes collected from Bos taurus indicus cows. With our investigation, we showed that 107 genes have altered expression due to the in vitro maturation system. Functional annotation of the data suggests that dysfunctional gene expression is not random and mostly affected the metabolism of oocytes. Inspection of the GO annotation of the genes suggests that one of the metabolic processes highly affected is the regulation of RNA synthesis. 


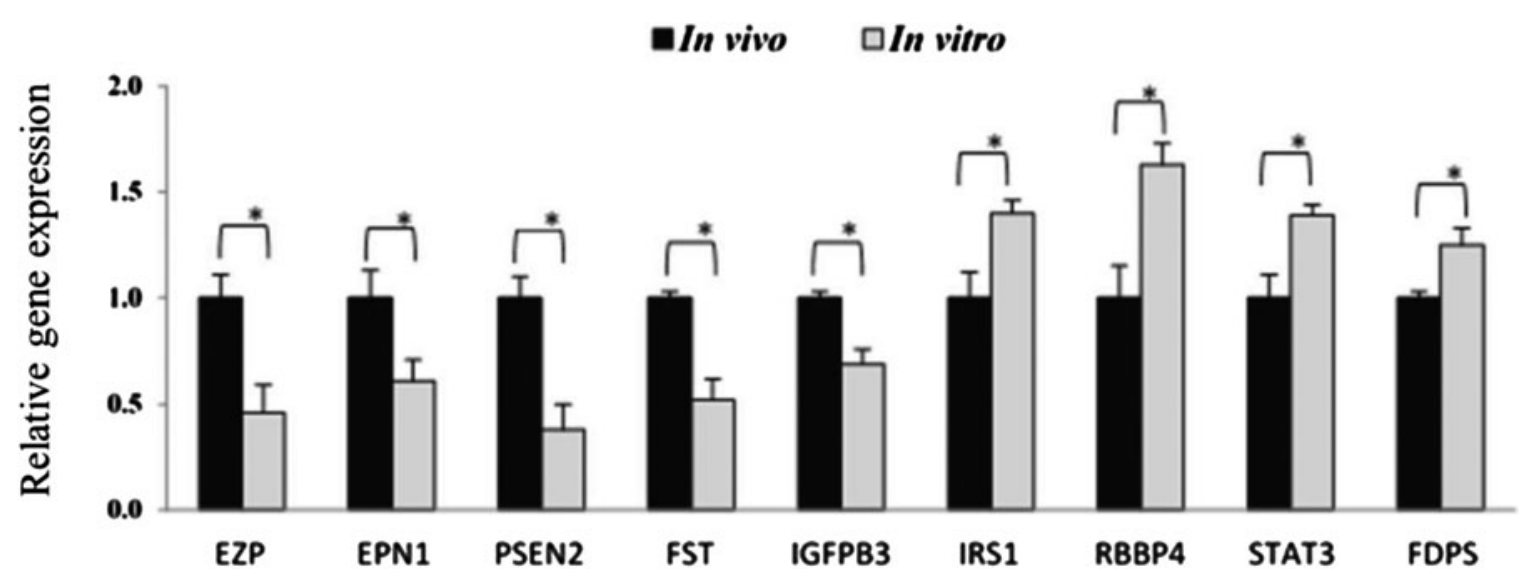

Figure 2 Relative expression of transcripts in in vivo- and in vitro-matured oocytes. Significant differences $(P<0.05)$ between groups (in vivo versus in vitro) are denoted by an asterisk. The results of three replicates are shown.

Corroborating our results, 21 of the DEGs were previously shown to be associated with oocyte developmental competence, 13 of those genes were up-regulated in in vivo-matured oocytes (DGKA (Beltman et al., 2010), GHR (Caixeta et al., 2009), FST (Bonnet et al., 2011), HMGB2 (Corcoran et al., 2007), TACC3 (Hao et al., 2002), IGFBP3 (Sawai 2009), EZR (Heng et al., 2011), KEAP1 (Powell et al., 2010), SMARCC1 (Lisboa et al., 2012), PLK1 (Sun et al., 2012), NGFRAP1 (Jiang et al., 2010), NUMA (Kolano et al., 2012) and EPN1 (Liu \& Zheng, 2009)) and eight of them were up-regulated in in vitro-matured oocytes [IRS-1 (Yamamoto-Honda et al., 1996), STAT3 (Mohammadi-Sangcheshmeh et al., 2011), CCNB1 (Liu et al., 2012), RBBP4 and RBBP7 (Gasca et al., 2008), ATF2 (Vigneault et al., 2009), TPX2 (Brunet et al., 2008) and HDAC2 (Caixeta et al., 2013)]. This observation supports our approach and analysis. Most importantly, we showed 86 new potential biomarkers associated with oocyte competence. Further investigation will be required to conclusively demonstrate that the transcription of these 86 genes are specifically altered in oocytes collected from B. taurus indicus and matured in vitro.

Functional analysis of the DEGs revealed that 37 genes were annotated to 'regulation of cellular metabolic process', which was previously shown to be important for the maturation of oocytes (Fair et al., 2007; Katz-Jaffe et al., 2009). Interestingly, 26 (of the 37) DEGs were also functionally related to 'negative regulation of cellular process', and those genes are potentially important for cytoplasmic maturation (Ferreira et al., 2009), and developmental potential of the oocytes. The dysregulation of a metabolic process such as the synthesis of RNA, due to in vitro maturation, is likely to affect the transcription during cleavage stages of development (Smith et al., 2009) and alter cleavage kinetics during embryo development (Knijn et al., 2003).

Our results of the transcriptome analysis were further supported by protein-protein interactome. The formation of protein-protein networks composed of the majority of genes either up-regulated (Fig. 1A) or down-regulated (Fig. $1 B$ ) regulated in in vivomatured oocytes strongly suggests biological coregulation of such genes in MII oocytes. Interestingly, we observed subsets of DEGs whose protein may form regulatory complexes (Fig. 1, insets). Two examples of gene co-expression and protein-protein interaction are potentially associated with gene regulation. First, the transcripts of MED29 and POLR2E are up-regulated in in vivo-matured oocytes, where this protein complex may function in the elongation phase of transcription (Takahashi et al., 2011). Second, we found the complex formed around the retinoblastoma binding protein 4 (RBBP4) in the genes up-regulated in in vitro-matured oocytes. The abnormal abundance of this complex may contribute to negative regulation of genes important for embryo development (Wolffe et al., 2000). These results showed that the in vitro culture system also disturbs the regulation of oocyte's gene expression at the transcriptional level.

In summary, we established the transcript profile of in vivo- and in vitro-matured oocytes of Bos taurus indicus cows using microarray technology. Our experiment allowed us to uncover genes potentially involved in the control of oocyte competence. In light of our results, we suggest that the harmonious function of metabolism and regulation of gene expression is pivotal for the acquisition of oocyte developmental competence. The identification of potential competence markers will be useful for developing better 
in vitro culture conditions to allow the oocyte to adequately obtain competence.

\section{Acknowledgements}

We thank Fundação de Amparo à Pesquisa do Estado de São Paulo (FAPESP 05/58702-4 and 05/596945) and Universidade de São Paulo (USP/FZEA) for financially supporting the project.

\section{References}

Ayres, M., Ayres, J.M., Ayres, D.L. \& Santos, A.S. (2007). BioEstat 5.0. Statistical Applications in Biological and Medical Sciences. Sociedade Civil Mamirauá, Brasília, CNPq, $138 \mathrm{pp}$.

Belli, M., Cimadomo, D., Merico, V., Redi, C.A., Garagna, S. \& Zuccotti, M. (2013). The NOBOX protein becomes undetectable in developmentally competent antral and ovulated oocytes. Int. J. Dev. Biol. 57, 35-9.

Beltman, M.E., Forde, N., Furney, P., Carter, F., Roche, J.F., Lonergan, P. \& Crowe, M.A. (2010). Characterisation of endometrial gene expression and metabolic parameters in beef heifers yielding viable or non-viable embryos on day 7 after insemination. Reprod. Fertil. Dev. 22, 987-99.

Benjamini, Y. \& Yekutieli, D. (2001). The control of the false discovery rate in multiple testing under dependency. Annals Stat. 29, 1165-88.

Bessa, I.R., Nishimura, R.C., Franco, M.M. \& Dode, M.A.N. (2013). Transcription profile of candidate genes for the acquisition of competence during oocyte growth in cattle. Reprod. Domest. Anim. 48, 781-9.

Biase, F.H., Fonseca Merighe, G.K., Santos-Biase, W., Martelli, L. \& Meirelles, F.V. (2008). Global poly(A) mRNA expression profile measured in individual bovine oocytes and cleavage embryos. Zygote 16, 29-38.

Biase, F.H., Martelli, L., Puga, R., Giuliatti, S., Santos-Biase, W.K., Fonseca Merighe, G.K. \& Meirelles, F.V. (2010). Messenger RNA expression of Pabpnl1 and Mbd3l2 genes in oocytes and cleavage embryos. Fertil. Steril. 93, 2507-12.

Biase, F.H., Everts, R.E., Oliveira, R., Santos-Biase, W.K., Fonseca Merighe, G.K., Smith, L.C., Martelli, L., Lewin, H. \& Meirelles, F.V. (2014). Messenger RNAs in metaphase II oocytes correlate with successful embryo development to the blastocyst stage. Zygote 22, 69-79.

Bonnet, A., Bevilacqua, C., Benne, F., Bodin, L., Cotinot, C., Liaubet, L., Sancristobal, M., Sarry, J., Terenina, E. \& Martin, P. (2011). Transcriptome profiling of sheep granulosa cells and oocytes during early follicular development obtained by laser capture microdissection. BMC Genomics 12, 417.

Bower, N.I., Moser, R.J., Hill, J.R., Lehnert, S.A. (2007). Universal reference method for real-time PCR gene expression analysis of preimplantation embryos. Biotechniques 42, 199-206.

Brunet, S., Dumont, J., Lee, K.W., Kinoshita, K., Hikal, P., Gruss, O.J., Maro, B. \& Verlhac, M.-H. (2008). Meiotic regulation of TPX2 protein levels governs cell cycle progression in mouse oocytes. PLoS One 3, e3338.
Caixeta, E.S., Ripamonte, P., Franco, M.M., Junior, J.B. \& Dode, M.A.N. (2009). Effect of follicle size on mRNA expression in cumulus cells and oocytes of Bos indicus: an approach to identify marker genes for developmental competence. Reprod. Fertil. Dev. 21, 655-64.

Caixeta, E.S., Sutton-McDowall, M.L., Gilchrist, R.B., Thompson, J.G., Price, C.A., Machado, M.F., Lima, P.F. \& Buratini, J. (2013). Bone morphogenetic protein 15 and fibroblast growth factor 10 enhance cumulus expansion, glucose uptake, and expression of genes in the ovulatory cascade during in vitro maturation of bovine cumulus-oocyte complexes. Reproduction 146, 27-35.

Chatr-Aryamontri, A., Breitkreutz, B.J., Heinicke, S., Boucher, L., Winter, A., Stark, C., Nixon, J., Ramage, L., Kolas, N., O'Donnell, L., Reguly, T., Breitkreutz, A., Sellam, A., Chen, D., Chang, C., Rust, J., Livstone, M., Oughtred, R., Dolinski, K. \& Tyers, M. (2013). The BioGRID interaction database: 2013 update. Nucleic Acids Res. 41, D816-23.

Corcoran, D., Rizos, D., Fair, T., Evans, A.C. \& Lonergan, P. (2007). Temporal expression of transcripts related to embryo quality in bovine embryos cultured from the twocell to blastocyst stage in vitro or in vivo. Mol. Reprod. Dev. 74, 972-977.

Fair, T., Carter, F., Park, S., Evans, A.C.O. \& Lonergan, P. (2007). Global gene expression analysis during bovine oocyte in vitro maturation. Theriogenology 68, S91-7.

Ferreira, E.M., Vireque, A.A., Adona, P.R., Meirelles, F.V., Ferriani, R.A. \& Navarro, P.A.A.S. (2009). Cytoplasmic maturation of bovine oocytes: structural and biochemical modifications and acquisition of developmental competence. Theriogenology 71, 836-48.

Gandolfi, T.A. \& Gandolfi, F. (2001). The maternal legacy to the embryo: cytoplasmic components and their effects on early development. Theriogenology 55, 1255-76.

Gasca, S., Pellestor, F., Assou, S., Loup, V., Anahory, T., Dechaud, H., De Vos, J. \& Hamamah, S. (2008). Identifying new human oocyte marker genes: a microarray approach. Reprod. Biomed. Online 14, 175-83.

Hao, Z., Stoler, M.H., Sen, B., Shore, A., Westbrook, A., Flickinger, C.J., Herr, J.C. \& Coonrod, S.A. (2002). TACC3 expression and localization in the murine egg and ovary. Mol. Reprod. Dev. 63, 291-9.

Heng, S., Cervero, A., Simon, C., Stephens, A.N., Li, Y., Zhang, J., Paule, S., Rainczuk, A., Singh, H. \& Quinonero, A. (2011). Proprotein convertase 5/6 is critical for embryo implantation in women: regulating receptivity by cleaving EBP50, modulating ezrin binding, and membrane-cytoskeletal interactions. Endocrinology 152, 5041-52.

Huang, D.W., Sherman, B.T. \& Lempicki, R.A. (2009). Systematic and integrative analysis of large gene lists using DAVID Bioinformatics Resources. Nat. Protoc. 4, 4457.

Jiang, J.-Y., Xiong, H., Cao, M., Xia, X., Sirard, M.-A. \& Tsang, B.K. (2010). Mural granulosa cell gene expression associated with oocyte developmental competence. J. Ovarian Res. 3, 6.

Kanka, J., Nemcova, L., Toralova, T., Vodickova-Kepkova, K., Vodicka, P., Jeseta, M. \& Machatkova, M. (2012). Association of the transcription profile of bovine oocytes 
and embryos with developmental potential. Anim. Reprod. Sci. 134, 29-35.

Katz-Jaffe, M.G., McCallie, B.R., Preis, K.A., Filipovits, J. \& Gardner, D.K. (2009). Transcriptome analysis of in vivo and in vitro matured bovine MII oocytes. Theriogenology 71, 939-46.

Knijn, H.M., Gjørret, J.O., Vos, P.L., Hendriksen, P.J., van der Weijden, B.C., Maddox-Hyttel, P. \& Dieleman, S.J. (2003). Consequences of in vivo development and subsequent culture on apoptosis, cell number, and blastocyst formation in bovine embryos. Biol. Reprod. 69, 1371-8.

Kolano, A., Brunet, S., Silk, A.D., Cleveland, D.W. \& Verlhac, M.-H. (2012). Error-prone mammalian female meiosis from silencing the spindle assembly checkpoint without normal interkinetochore tension. Proc. Natl. Acad. Sci. 109, E1858-67.

Labrecque, R., Vigneault, C., Blondin, P. \& Sirard, M.A. (2013). Gene expression analysis of bovine oocytes with high developmental competence obtained from FSHstimulated animals. Mol. Reprod. Dev. 80, 428-40.

Li, Y., Ray, D. \& Ye, P. (2013). Identification of germ cellspecific genes in mammalian meiotic prophase. BMC Bioinform. 14, 1-13.

Lisboa, L.A., Bordignon, V. \& Seneda, M.M. (2012). Immunolocalization of BRG1-SWI/SNF protein during folliculogenesis in the porcine ovary. Zygote 20, 243-8.

Liu, Z. \& Zheng, Y. (2009). A requirement for epsin in mitotic membrane and spindle organization. J. Cell Biol. 186, 47380.

Liu, W., Yin, J., Zhao, G., Yun, Y., Wu, S., Jones, K.T. \& Lei, A. (2012). Differential regulation of cyclin B1 degradation between the first and second meiotic divisions of bovine oocytes. Theriogenology 78, 1171-81.

Livak, K.J. \& Schmittgen, T.D. (2001). Analysis of relative gene expression data using real-time quantitative PCR and the $2^{-\Delta \Delta C T}$ method. Methods 25, 402-8.

Mohammadi-Sangcheshmeh, A., Held, E., Ghanem, N., Rings, F., Salilew-Wondim, D., Tesfaye, D., Sieme, H., Schellander, K. \& Hoelker, M. (2011). G6PDH-activity in equine oocytes correlates with morphology, expression of candidate genes for viability, and preimplantative in vitro development. Theriogenology 76, 1215-26.

Niemann, H., Carnwath, J.W. \& Kues, W. (2007). Application of DNA array technology to mammalian embryos. Theriogenology 68, S165-77.

Pocar, P., Brevini, T.A.L., Perazzoli, F., Cillo, F., Modina, S. \& Gandolfi, F. (2001). Cellular and molecular mechanisms mediating the effects of polychlorinated biphenyls on oocyte developmental competence in cattle. Mol. Reprod. Dev. 60, 535-41.

Powell, M.D., Manandhar, G., Spate, L., Sutovsky, M., Zimmerman, S., Sachdev, S.C., Hannink, M., Prather, R.S. \& Sutovsky, P. (2010). Discovery of putative oocyte quality markers by comparative ExacTag proteomics. PROTEOMICS - Clinical Applications 4, 337-51.
Sawai, K. (2009). Studies on gene expression in bovine embryos derived from somatic cell nuclear transfer. $J$. Reprod. Dev. 55, 11-6.

Shannon, P., Markiel, A., Ozier, O., Baliga, N.S., Wang, J.T., Ramage, D., Amin, N., Schwikowski, B. \& Ideker, T. (2003). Cytoscape: a software environment for integrated models of biomolecular interaction networks. Genome Res. 13, 2498-504.

Sirard, M.-A., Richard, F., Blondin, P. \& Robert, C. (2006). Contribution of the oocyte to embryo quality. Theriogenology 65, 126-36.

Smith, S.L., Everts, R.E., Sung, L.Y., Du, F., Page, R.L., Henderson, B., Rodriguez-Zas, S.L., Nedambale, T.L., Renard, J.P., Lewin, H.A., Yang, X., Tian, X.C. (2009). Gene expression profiling of single bovine embryos uncovers significant effects of in vitro maturation, fertilization and culture. Mol. Reprod. Dev. 76, 38-47.

Smyth, G.K. (2005). Limma: linear models for microarray data. In Bioinformatics and computational biology solutions using $R$ and Bioconductor (R. Gentleman, V. Carey, W. Huber, R. Irizarry \& S. Dudoit, eds), pp. 397-420. Springer.

Smyth, G.K. \& Speed, T. (2003). Normalization of cDNA microarray data. Methods 31, 265-273.

Sun, S.-C., Liu, H.-L. \& Sun, Q.-Y. (2012). Survivin regulates Plk1 localization to kinetochore in mouse oocyte meiosis. Biochem. Biophys. Res. Commun. 421, 797-800.

Takahashi, H., Parmely, T.J., Sato, S., Tomomori-Sato, C., Banks, C.A., Kong, S.E., Szutorisz, H., Swanson, S.K., Martin-Brown, S., Washburn, M.P., Florens, L., Seidel, C.W., Lin, C., Smith, E.R., Shilatifard, A., Conaway, R.C. \& Conaway, J.W. (2011). Human mediator subunit MED26 functions as a docking site for transcription elongation factors. Cell 146, 92-104.

Tomek, W., Torner, H. \& Kanitz, W. (2002). Comparative analysis of protein synthesis, transcription and cytoplasmic polyadenylation of mRNA during maturation of bovine oocytes in vitro. Reprod. Domest. Anim. 37, 86-91.

Vigneault, C., McGraw, S. \& Sirard, M.-A. (2009). Spatiotemporal expression of transcriptional regulators in concert with the maternal-to-embryonic transition during bovine in vitro embryogenesis. Reproduction 137, 13-21.

Wolffe, A.P., Urnov, F.D. \& Guschin, D. (2000). Co-repressor complexes and remodelling chromatin for repression. Biochem. Soc. Trans. 28, 379-86.

Yamamoto-Honda, R., Honda, Z.I., Ueki, K., Tobe, K., Kaburagi, Y., Takahashi, Y., Tamemoto, H., Suzuki, T., Itoh, K. \& Akanuma, Y. (1996). Mutant of insulin receptor substrate-1 incapable of activating phosphatidylinositol 3kinase did not mediate insulin-stimulated maturation of Xenopus laevis oocytes. J. Biol. Chem. 271, 28677-81.

Yu, J., Hecht, N.B. \& Schultz, R.M. (2002). RNA-binding properties and translation repression in vitro by germ cellspecific MSY2 protein. Biol. Reprod. 67, 1093-8.

Yuan, J.S., Reed, A., Chen, F. \& Stewart, C.N., Jr (2006). Statistical analysis of real-time PCR data. BMC Bioinformatics 7,85 . 